\title{
Inclusive Growth and Excellence: Fascinating Journey in Kiss Odisha
}

\author{
Dr. Monalisa Bal ${ }^{1}$ \\ ${ }^{I}$ Chairperson, KIIT International School, Campu-9, KIIT University, Bhubaneswar-751024
}

\begin{abstract}
The social reform movements in India have consistently championed the cause of oneness of Indian Society and the under privileged. Dr. Ambedkar, as Father of the Constituent Assembly provided significant constitutional safeguards to SC/ST with a view to ensuring equality of opportunity and preemption of discrimination. However, inclusive growth interms of equal access to nutritious food, education and meaningful employment has remained a chimera. The tribals who constitute $23 \%$ of Odisha's population have the added disadvantage of being alienated. The fruits of liberalization have not impacted tribals Below Poverty Line (BPL) compared to the general category. The paper analyses the various facets of inequity viz. educational opportunity, employment etc. in different segments of our society and brings out a case study of remarkable reform movement for the tribals in Kalinga Institute of Social Sciences (KISS) Odisha by ensuring a better livelihood prospect, special focus on girl child education, reduction in Gender Inequality Index (GII), improving Gross Enrolment Ratio (GER) and significant employment opportunities through international collaboration with UNFPA \& UNICEF.
\end{abstract}

Keywords: BPL, KISS, GII, GER, UNFPA, UNICEF

\section{Introduction}

The Indian Constitution professes equal opportunity in access to education to all sections of society, irrespective of caste, sect, religion or gender. There are also positive provisions to bolster educational and employment opportunities for SC \& ST by providing reservation and even accelerated promotion. The Supreme Court in Indira Sawney Case (1992) and subsequently in Nagraj Vs. Union of India Case (2005) have viewed preconditions such positive discrimination as necessary to realize the ideals of Directive Principles of State Policy. Besides these affirmative provisions, financial inclusion was ushered through Bank Nationalization in 1969 \& subsequently through MGNREGA, Right to Education \& Right to Food. Studies have shown that the MGNREGA programme has benefitted the SC \& ST community significantly. While Right to Education provision in Article 21A has improved access to education in the primary education segment there are disturbing evidence that such benefit is not percolating down to SC \& ST in equal measure, as much as in the general category in higher education. The benefit of liberalization seems to be not to have benefited the disadvantaged sections like ST below poverty line in equal measure. The STs who constitute $23 \%$ of Odisha's population, the problem has been one of alienation, acute poverty fostering a spate of Maoist violence in the tribal belt. A very pioneering initiative has been taken by the philanthropist Dr. Achyuta Samanta a decade back to actualize the twin objectives of mainstreaming the alienated tribals and empowering them with meaningful vocational skills, quality education and employment opportunity.

\section{The paper examines}

- Impact of Education Policy Initiatives in Fostering Equity amongst SC/ST

- Need For Universalization Of Basic Services \& Improvement In Human Development Index

- Outcome of focused attempt to end Alienation and ensure Empowerment amongst tribal students in KISS

\section{Impact Of Education Policy Initiatives In Fostering Equity Amongst Sc/St}

The $12^{\text {th }}$ Plan flags Equity, Access and Excellence as the major corner stones for higher education in India. While the Gross Enrolment Rate has increased twofold from 2000, i.e. 9.7\% to $16.8 \%$ in 2012, largely due to private sector entry in the field of technical degree courses, the impact on different sections of the society has been asymmetric.

The following two tables brings-out this dissonance.

Table-1- Impact of Access to Education on different Sections of Society

\begin{tabular}{|l|l|l|l|}
\hline Grouping & $\mathbf{1 9 9 9 - 2 0 0 0}$ & $\mathbf{2 0 0 7 - 2 0 0 8}$ & Population Share \\
\hline SC & 5.1 & 11.6 & 16 \\
\hline ST & 6.4 & 7.7 & 7 \\
\hline
\end{tabular}




\begin{tabular}{|l|l|l|l|}
\hline MUSLIM & - & 9.6 & 13 \\
\hline OBC & 7.1 & 14.8 & 27 \\
\hline National Average & 10.1 & 17.2 & 100 \\
\hline
\end{tabular}

Source: National Sample Survey Organization Data 2006

It would thus be seen from Table-1 that while there has been considerable improvement in access to education; the SC, ST \& Muslims do not have access to higher education commensurate with their population share. However, the Muslims, seem to be significantly lagging behind in terms of their representation in higher education despite implementation of the Sachhar Committee Report (2006) in a substantial measure.

Besides different regions of India present a varied picture in terms of access to higher education. Southern States lead the pack; while apathy rules the roost in Central and North-Central India as the Table-2 would reveal.

Table-2- Access to Higher Education: Inter Region

\begin{tabular}{|l|l|l|l|l|}
\hline Region & SC/STs & Muslims & Hindus OBC & Hindus Upper Level \\
\hline South & 7 & 8 & 12 & 26 \\
\hline North & 7 & 7 & 11 & 26 \\
\hline North-Central & 4 & 3 & 6 & 20 \\
\hline Central & 3 & 5 & 6 & 25 \\
\hline Western & 5 & 7 & 9 & 25 \\
\hline North-Eastern & 3 & 3 & 6 & 13 \\
\hline
\end{tabular}

Source: National Sample Survey Organization Data 2006

\subsection{Impact of Liberalization on Poverty \& Literacy:}

Table-3-Impact of Liberalization on Poverty

\begin{tabular}{|l|l|l|l|}
\hline Category & $\mathbf{1 9 7 7 - 7 8}$ & $\mathbf{2 0 0 4 - 2 0 0 5}$ & Population<BPL (M) \\
\hline General & 51 & 27 & 256 \\
\hline ST & 59 & 38 & 75 \\
\hline SC & 65 & 46 & 40 \\
\hline & & & $\mathbf{3 7 1 M}$
\end{tabular}

Source: India's Economic Reforms and Development by Isher Judge Ahluwalia \& IMD Little, Oxford India Perennials, Second Edition

It would be seen from the above that the impact on poverty reduction has been less significant in case of scheduled tribe compared to the general category and they constitute close to 100 million now languishing in acute poverty, illiteracy and alienation in remote forests.

The following table makes a comparison for across the gender for general category and ST both for all India and in Odisha. While tribals constitutes $\mathbf{7 \%}$ of the total population in India in Odisha it is account for $\mathbf{2 3 \%}$.

Table-4-Impact of Liberalization on Literacy

\begin{tabular}{|l|l|l|l|l|l|l|}
\hline Parameter & \multicolumn{4}{|l|}{ General Category } & \multicolumn{2}{l|}{ Scheduled Tribe } \\
\hline & Male & Female & Total & Male & Female & Total \\
\hline All India (Literacy) & 78.5 & 58.7 & 68.9 & 57 & 40.4 & 49 \\
\hline Odisha & 80.4 & 61 & 70.7 & 53 & 34.8 & 43.9 \\
\hline
\end{tabular}

This has important lesson for India who HDI is very low and public investment in education very low compared to developed countries. The table below brings out the picture.

\subsection{Gross Enrolment Ratio of Tribals}

The GER (Gross Enrolment Ratio) of STs in Higher Education in the State is 6\% against as State's GER of $16.1 \%$. The position of STS in access to Higher Education in India and Odisha is as under.

Table-5-Gross Enrolment Ratio: All India \& Odisha

\begin{tabular}{|l|l|l|}
\hline & \% of Population & GER \\
\hline All India & $7 \%$ & $4.4 \%$ \\
\hline Odisha & $24 \%$ & $6 \%$ \\
\hline
\end{tabular}

Source: ASHE 2013 Annual Status of Higher Education of States and UTs in India November 2013 Deloitte

It would be seen, that in case of females the literacy per cent of tribals is particularly disconcertingly low in Odisha. The Right to Education (RTE) has a mandate to have a school within one kilometer of radius of every habitation in order to ensure that every child gets the facility of a nearby school. The absence of basic amenities like toilet facilities, safe drinking water, and shortage of staff are areas of serious concern. The Economy Survey (2013-2014) notes that there is a need to look at the quality of teachers and regularization of temporary teachers. Prime Minister Modi has also highlighted the need for setting-up schools in nearby the 
villages so that the dropout rate amongst girl's children gets reduced significantly. He has also highlighted the need for providing clean toilet facilities by 2015. These are welcome initiatives. However, the ground reality in terms of infrastructure and quality of teachers remains really grim; particularly in remote locations where STs reside.

\section{Need For Universalization Of Basic Services \& Improvement In Human Development Index}

Universal coverage of basic social services-education, health care, water supply and sanitation is not only an imperative but a powerful way of directly addressing the uncertain nature of vulnerability that disadvantaged sections of the society face. It would be interesting to recount the experience of a few countries in this regard. Sweden made schooling compulsory for all children in 1842. Germany initiated education for the masses under the Russian rule. Republic of Korea invested heavily in education in the late 1940's and continues to expand access to education even during political turmoil of the 1950s. Srilanka achieved near universal education and health care despite of years of militancy and war through conscious public policy. Expanded education and health care have enabled several countries to reach, rich demographic dividend. In Korea for instance only $5 \%$ of population had secondary or higher education. However by 1990 s the high school graduation enrolment was $90 \%$ and their Mean Years of Schooling is $11.5 \%$ which is at par with every advanced countries as per the Human Development Report 2014.

India ranks very poorly interms of human development index. This is largely due to inadequate public investment in education and research and development. As would be seen from the table below giving global comparison.

Table-6- HDI, Public Spending \& Education Quality Index*

\begin{tabular}{|l|l|l|l|l|l|l|}
\hline Country & HDI & Public Spending & Reading & Math & Science & \% Satisfied \\
\hline USA & 0.937 & $5.4 \%$ & 500 & 487 & 502 & $62.8 \%$ \\
\hline Germany & 0.92 & $4.6 \%$ & 497 & 513 & 520 & 65.6 \\
\hline Japan & 0.912 & $3.8 \%$ & 520 & 529 & 539 & 54.6 \\
\hline Korea & 0.909 & $5 \%$ & 542 & 546 & 538 & 50.5 \\
\hline China & 0.7 & $3 \%$ & 556 & 600 & 575 & 62.6 \\
\hline Russia & 0.788 & $4 \%$ & 459 & 468 & 478 & 38 \\
\hline Brazil & 0.73 & $5.7 \%$ & 412 & 386 & 405 & 53.7 \\
\hline India & 0.554 & $3.1 \%$ & - & - & - & - \\
\hline
\end{tabular}

* 15years students in subject essential for participation in society

Source: HDR 2013

\section{Outcome Of Focused Attempt To End Alienation And Ensure Empowerment} Amongst Tribal Students In Kiss Odisha

\subsection{Social Reform Movements}

Raja Ram Mohan Roy was the pioneer for oneness of India through Bramho Samaj, Jyoti Rao Phule through his Satya Sadhok Samaj, and Ambedkar by championing the cause of the Scheduled Caste. To a question as to why he did not take-up tribal questions, B.R. Ambedkar had answered "I have never claimed to be the universal leader of suffering humanities. The problem of untouchables is quite enough for my suffering strength".

It was left to Verrier Elwin (1902-1964) who addressed the issue alienation assimilation of tribals into the main stream in a significant way. Given his overwhelming commitment to the tribal cause Pandit Nehru appointed him as an adviser on tribal affairs in NEFA. He lived in central India and wrote extensively on the exploitative land and forest policies. He was prophetic when he said "We can solve their problem if we do not try to go too fast: if we allow them a breathing space in which to adjust themselves to the new world; and if we go to them in genuine love and true simplicity.

\subsection{Success Story of KISS}

The story of KISS was born after three decades, as if through serendipity, thanks to the un-wavering efforts of its Founder and mentor Dr. Achyuta Samanta. Home to nearly 22000 tribal students, KISS receives application from 2.2lakh applicants every year for three thousand seats reserved for tribal students in KIIT University. The institutions run with uncommon élan with a budget of around R. 75 crore of which around Rs. 25 crores comes through donation from staffs and officers from KIIT University and the rest is from philanthropy and financial aid. The primary objective of KISS is to provide inclusive and holistic education to the marginalized tribal students who would have been otherwise caught in the quagmire of illiteracy, impoverishment \& violence. 
The defining success of KISS can be Summed-up as under-

\section{- Quality Education with a Special Focus on Girl Child Education}

KISS has been able to address many of the social and health issues like child marriage, infant mortality and maternal mortality etc. Girls in the indigenous communities are generally married off at an early age. They have little or no knowledge about their bodies and healthy sexual and reproductive practices, leading to high maternal mortality and infant mortality in these communities. Since the girls pursue education at KISS they free from the societal pressure of marrying at an early age. Secondly the girls are provided counseling and education on their sexual reproductive health and rights at KISS which enables the girls to have a better understanding of their own bodies and healthy sexual and reproductive practices. This in turn led to reduction of maternal mortality and infant mortality among them.

\section{- Life Skills Education}

KISS has been implementing 'Life Skills Education' institution with the support of United Nation Population Fund (UNFPA). The objective behind it is to build the capacity of the tribal adolescents so that they could deal with different issues in their lives effectively. KISS has also been implementing this programme in all the 30 districts of the state reaching out directly to 80,000 children in the age group of 10-14 years. Indirectly KISS has been reaching out to a population of 4 lakhs all over the state.

\section{- Hunger \& Health Alleviation}

The greatest achievement has been the ability to provide three nutritious meals each day to all 20,000 students. Indigenous communities also have lower levels of
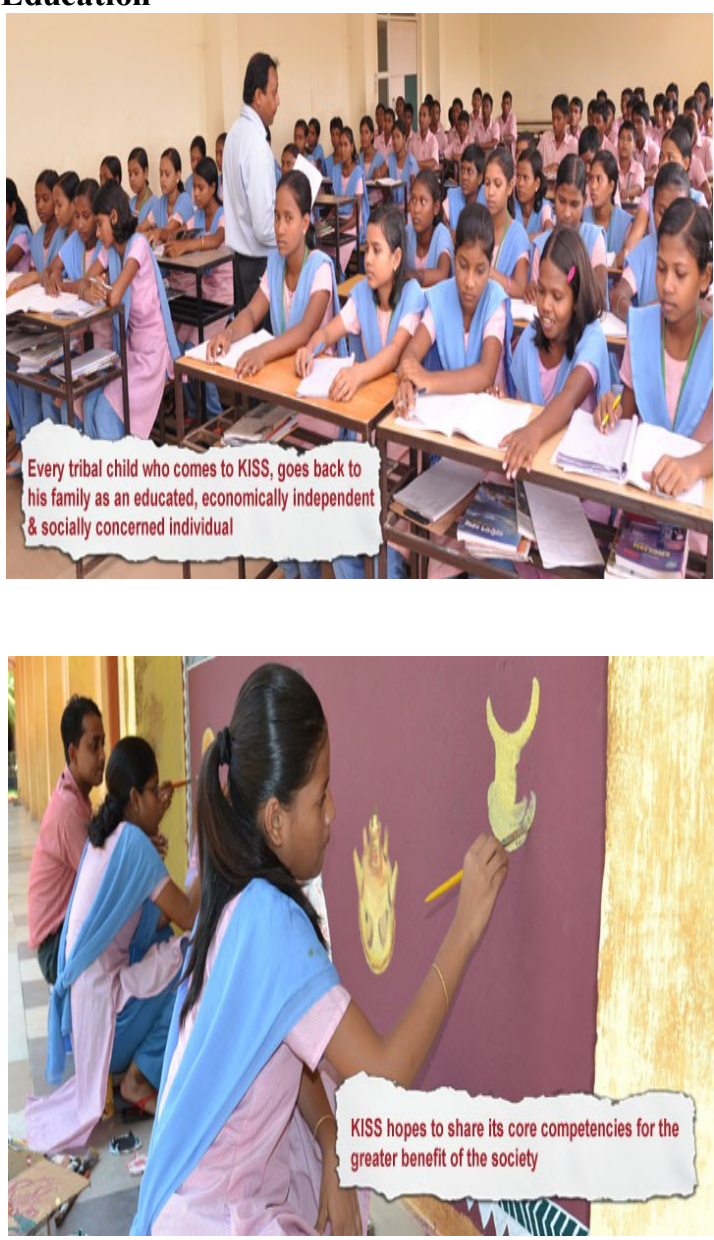
awareness on health issues which is a major reason why children are subjected to many serious diseases and illnesses such as Kwashiorkor, Marasmus, Tuberculosis, hookworm and ringworm infestation to name a few. Malnutrition and under nutrition is highly prevalent among the children in these communities. Conditions like Kwashiorkor and Marasmus arise due to vitamin and protein deficiencies in the body. KISS ensures that the diet provided is enriched with vitamins, proteins, minerals and carbohydrates.

\subsection{Unemployment Mitigation}

KISS has, to a certain extent, been able to address the issue of unemployment. The students at KISS have been able to find a source of livelihood after completion of their education. Many students have been placed in the public and private sector jobs and those students who have acquired degrees in medicine, engineering etc are now at par with the general population. The students are also provided with vocational trainings in different trades; the most popular being food preservation, fish cultivation, mushroom cultivation and agricultural practices. KISS in collaboration with the British Council has taken up a unique Self Employment Programme with focus on young girls, imparting them prerequisite skill-sets to establish social enterprises (food preservation) in their villages.

\subsection{International Collaboration}

\section{- English Access Micro Scholarship Program}

This program is an initiative of the Department of State, United States of America. 450 tribal students have been enrolled in this program and are being trained in English language so that they can be empowered to compete at a national and international level.

\section{- Bernard Van Leer Foundation}

Kalinga Institute of Social Sciences (KISS), in collaboration with Bernard van Leer Foundation, is instituting the first Early Childhood Development Program through Mother Tongue based multilingual learning 
in the state within its premises. This program not only aims to improve the quality of education of children getting enrolled into KISS, but also aims to be the first Centre of Excellence on mother tongue based early childhood education in the state.

\section{- United Nations Population Fund (UNFPA)}

KISS in partnership with United Nations Population Fund (UNPFA) is implementing a project on "Empowering young people with life skills through building institutional capacity, imparting life skills education and broadening research base for Adolescent Reproductive and Sexual Health (ARSH) and Life Skill Education (LSE)" for about 5000 adolescents in the institute and extend support for promotion of LSE \& ARSH in the region from October 2009.

\section{- United Nations Children's Fund (UNICEF)}

UNICEF in association with KISS has established a Children Development Resource Centre (CDRC) as part of the larger UNICEF-KIIT University joint initiative for the Centre for Children Studies (CCS). The goal is to promote evidence-based policy making by building a knowledge base through action research and other development programmes on children's issues focusing on the state of Odisha.

\subsection{Excellence in Academics and Athletics}

There are nearly 4657 students having the benefit of higher education with almost 50:50 participation of boys and girls. Some of the significant academic achievements have been $97 \%$ result in +2 Science, Arts and Commerce \& 100\% result in Post-Graduation. Thirteen students of KISS have qualified for the Rajiv Gandhi National Fellowship for 2012- 13, four Students recruited by Odisha Grameen Bank, four Students recruited by Railway recruitment Board, twenty Four Students have been recruited as teachers under the Sarba Siksha Abhiyaan Scheme of Government of Odisha and eight students were selected by TCS in Campus recruitment Drive. In terms of extracurricular activities Shri B. Barik was selected for Women Rugby World Cup and Shri L. Hembram: UN Youth Assembly at Malala.

It would thus be seen that a uniquely innovative project for mainstreaming the tribal students through education is not only ensuring not only $100 \%$ success at $10+$ level, but also ensuring that some of them compete successfully in converted jobs in Banks, Railway, IT sectors and even Civil Services Examination under the guidance of School of Leadership.

\section{Conclusion}

Prof. Richard Musgrave, the high priest of public finance had said that public policy is all about allocational choice, distributive justice and economic stabilization. The GOI has shown a continuity in its commitment towards social sector programmes. In KISS, a unique financial model has been put in place where expenditure per students is really minimal Rs.99.62 per day (\$1.63) (food, maintenance, salary of support staff $\&$ teacher) as against (\$14) spent by students in other schools of KIIT university.

KISS does not receive any financial aid/support either from the State government or from the Central government. The support of international organizations like UNICEF \& UNFPA \& Bernard Van Leer Foundation is for life skill improvement. In the interest of inclusive growth and assimilation of tribal students in to the mainstream with true empowerment, there is a strong case for governmental financial support both in the form of scholarships financial loan and allocation to the major ongoing programmes in KISS.

The movement towards social inclusivity has been guaranteed through our Constitution. The last decade has witnessed significant policy in terms of financial inclusion in terms of RTE, NREGA \& Right to Food. However, the asymmetry in access to education and community, social and economic empowerment in respect of the tribal community has been a distressing chapter in India's development story. The contribution of Dr. Samanta is, therefore unique despite the heaviest of odds. Martin Luther King Jr. had said "Human progress is neither automatic nor inevitable. Dr. Samanta by establishing

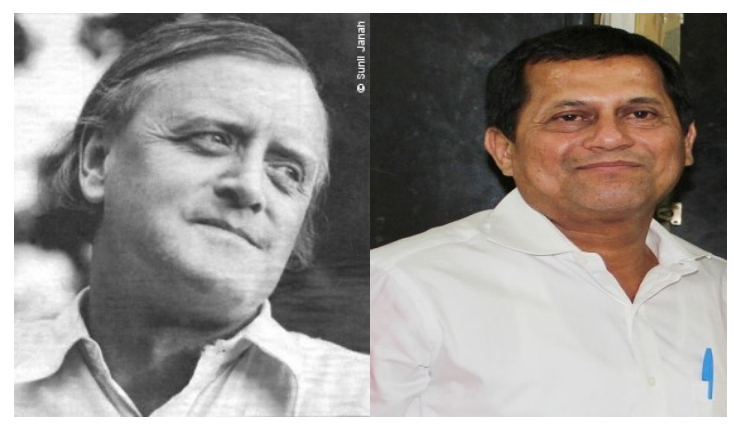
KISS and mentoring it with 'genuine love' and 'true simplicity', a hope fondly espoused by Verrier Elwin carries his legacy forward for unbelievable progress of tribal children".

\section{Acknowledgement}

I acknowledge input received from Dr. S.N. Misra, Director, School of Leadership. 


\section{References}

[1] Altbach, G.P.(2009). The Giants Awake: Higher Education Systems in China and India. Economic \& Political Weekly, June 6, 2009 VOL XLIV No 23

[2] Annual Report, Ministry of Human Resource Development, India, 2010-11 \& 12-13

[3] Dreze, J. \& Sen, (2013) A. An Uncertain Glory India and its Contradictions. Penguin Books India Pvt. Ltd, Panchsheel Park, New Delhi

[4] Economic Survey 2013-2014, Government of India

[5] Human Development Report, 2014-Sustaining Human Progress: Reducing Vulnerabilities and Building Resilience-UNDP

[6] India's Budget Document 2014-2015

[7] Weisskopf, T.E. Consequences of Affirmative Action in US Higher Education - A Review of Recent Empirical Studies. Economic and Political Weekly December 22, 2001

[8] Guha, R. Makers of Modern India. Penguin Book India Pvt. Ltd, New Delhi

[9] Sachs, J. The Price of Civilization-Reawakening Virtue and Prosperity after the Economic Fall. Vintage, Random House, 20 Vauxhall Bridge Road, London, 2012

[10] American Research Foundation, KISS-An Innovative Model of Education 